\title{
RICE SEED PRIMING
}

\section{CONDICIONAMENTO FISIOLÓGICO DE SEMENTES DE ARROZ}

\author{
Vanessa Neumann SILVA ${ }^{1}$; Juliana da Rosa da SILVA ${ }^{2}$ \\ 1. Professora Adjunta, Doutora em Fitotecnia, Universidade Federal do Pampa, campus Itaqui, Itaqui, RS, Brasil. \\ vanessaneumann@unipampa.edu.br; 2. Engenheira Agrônoma, Universidade Federal do Pampa, campus Itaqui, Itaqui,RS, Brasil.
}

\begin{abstract}
The priming is a technique that involves the controlled hydration of seeds up to allows the start of germination preparatory processes without permit radicle protrusion. The aim of this study was to evaluate the effect of different procedures of priming on physiological potential of rice seeds. Seeds of rice cultivars Puita Inta Inov CL and CL, each represented by a lot were used. The treatments consisted of: control, hydropriming, priming with Stimulate ${ }^{\circledR}$, boric acid solution and zinc sulfate solution, with four replications. Prior to priming, the seeds hydration curves were determining. After priming, the seeds evaluated for germination, seedling growth, efficiency of use of the endosperm, germination at lowest temperatures and seedling emergence. Priming procedures used in this study does not improve rice seed physiological potential, of cultivars Puita Inta CL and Inov Cl. Seed priming with boric acid has a negative effect on seed performance.
\end{abstract}

KEYWORDS: Oryza sativa. Zinc. Boric acid. Stimulate ${ }^{\circledR}$

\section{INTRODUCTION}

Seed priming is a technique that comprises controlled seed hydration to achieve a sufficient level to enable the preparatory processes essential for germination, without allowing protrusion of the primary root. Different procedures may be used for carrying out priming, according to the established type of methodology for the supply of water to seeds. Priming can involve different matrices and other conditions that regulate seed moisture content; this can be achieved through the use of various aqueous solutions, solid particulate systems and a spectrum of controlled moisture contents (TAYLOR et al., 1998).

Recently, it has been suggested that priming can be achieved with micronutrients (MUHAMMAD et al., 2015; MUHAMMAD et al., 2013; ZANAN et al. 2012). According to Farooq et al. (2012), application of micronutrients by seed treatment may be considered a better alternative in many cases, compared to other methods. According to these authors, seed priming with zinc ( $\mathrm{Zn})$ can increase seedling emergence, establishment and subsequent growth as well as productivity. Imran et al. (2013) found that the priming of corn seeds with nutrients promoted greater plant growth up to 5 weeks after sowing under field conditions.

Working with barley seeds, Ajouri et al. (2004) found that $\mathrm{Zn}$ seed conditioning caused increases in germination and seedling development. Also, Johnson et al. (2005) reported improved germination in rice seeds primed with a zinc sulfate solution. Ozturk et al. (2006) found an increased amount of $\mathrm{Zn}$ in wheat coleoptiles and roots during germination (up to $200 \mathrm{mg} \mathrm{kg}^{-1}$ ), thus highlighting the involvement of this element in physiological processes during early seedling development, possibly in protein synthesis and membrane function (CAKMAK, 2000). Another important micronutrient is boron. Rehman et al. (2013) reported that rice seed conditioning with boric acid resulted in greater establishment of rice seedlings. However, there have been few studies regarding the use of $B$ in seed priming.

Another type of seed priming is the use of solutions of plant growth regulators. Ghobadi et al. (2012) reported that wheat seed conditioning with gibberellic acid (50 ppm for $24 \mathrm{~h}$ ) provided higher germination and seedling growth. Yarnia and Tabrizi (2012) found improvements in onion seed germination and seedlings growth with seed conditioned with AIA, GA $\mathrm{GA}_{3}$ and kinetin. Santos et al. (2013) found that sunflower seed conditioning with Stimulate ${ }^{\circledR}$ increased germination, promoting the formation of more vigorous seedlings, reducing the percentage of abnormal seedlings and promoting a higher percentage of seedling emergence.

However, for rice, there is no recommended methodology for seed priming, so the aim of this study was to evaluate the effect of different priming procedures on physiological potential of rice seeds.

\section{MATERIAL AND METHODS}

In this research, rice seed cultivars Puita Inta $C L$ and $C L$ Inov were used, each one represented by one lot, which had 95 and $92 \%$ germination, respectively. The treatments consisted of: control (no priming), hydropriming, priming 
with Stimulate ${ }^{\circledR}$ at $0.5 \mathrm{~L}^{-1} 100 \mathrm{~kg}^{-1}$ seed, priming with boric acid solution at $0.008 \mathrm{M}$ (JOHNSON et al., 2005) and priming with zinc sulfate solution at 0.004 M (JOHNSON et al., 2005), with four replicates. Before priming procedures, imbibition curves were performed to allow for the determination of the optimum time for priming.

\section{Imbibition curves}

Four replicates of $5 \mathrm{~g}$ of seeds of each cultivar were distributed on three sheets of germination paper and covered with more three sheets, the placed on a metallic screen attached to a plastic box $(11 \times 11 \times 3.5 \mathrm{~cm})$ containing $40 \mathrm{ml}$ of distilled water inside or solutions containing boric acid, zinc sulfate or Stimulate ${ }^{\circledR}$. They were taken to a germination chamber set at $25^{\circ} \mathrm{C}$, where they remained until the primary root emission; during this period, samples were taken every hour during the first 12 hours of soaking and every three hours from this point until root protrusion occurred; seeds were then weighed on a precision balance $(0.0001$ g). Based on these data, the amount of water/solution absorbed by the seeds was calculated for each treatment and imbibition curves were prepared to determine the appropriate period for the interruption of the procedure, which was used to perform priming. Seed priming was done similarly to the procedure used for imbibition curves, and the seeds remained for the following periods: 25 to 31 hours for Puita and Inov cultivars, respectively; for hydropriming, 31 and 32 hours for Puita and Inov cultivars, respectively; for priming with Stimulate $\AA$, 35 and 37 hours for Puita and Inov cultivars, respectively; for priming with boric acid and 30 and 35 hours, and for Puita and Inov cultivars, respectively, in conditioning with $\mathrm{Zn}$ sulfate.

After priming, seeds were evaluated for germination and physiological potential, according to the methodology described below.

\section{Germination test}

Four replications of 50 seeds for each treatment, for each cultivar, were placed in germitest paper rolls, made up of three leaves moistened with distilled water, with the amount of water equivalent to 2.5 times the weight of dry paper. Next, rolls containing the seeds were transferred to a germination chamber at $25^{\circ} \mathrm{C}$, where they remained for 14 days. Evaluations were made at 5 and 14 days after sowing according to the criteria of the Brazilian Rules for Seed Testing (BRAZIL, 2009).

\section{Seedling growth test}

Four replicates of 20 randomly chosen seedlings per treatment from the germination test, for each cultivar, were measured manually with the aid of a graduated scale, with the results expressed in centimeters (NAKAGAWA, 1999). Then, the seedlings were transferred to paper bags and dried in an oven at $65^{\circ} \mathrm{C}$ with forced air circulation until constant weight; after this, seedlings were weighted on a precision balance (0.001 grams) to obtain the dry weight of seedlings, expressed in grams (NAKAGAWA, 1999). After this, the values were divided by 20 to obtain the dry matter produced per plant and converted into $\mathrm{mg}$.

\section{Germination test at low temperature}

The procedure was carried out similarly to the standard germination test (BRAZIL, 2009), as described above, differing only by keeping the seeds in a germination chamber at $10^{\circ} \mathrm{C}$ for 48 hours; then, seeds were transferred to the a chamber at $25^{\circ} \mathrm{C}$, with an evaluation 14 DAS (days after sowing).

\section{Seedling growth at low temperature}

This was conducted similarly to the standard germination test, differing only by keeping the seeds in a germination chamber at $10^{\circ} \mathrm{C}$ for 48 hours; then, seeds were transferred to a chamber at $25^{\circ} \mathrm{C}$, with an evaluation 14 DAS.

\section{Seedling emergence test}

Four replications of 50 seeds per treatment, for each cultivar separately, were sown in pots with $6 \mathrm{~kg}$ of sand, screened and washed, $3 \mathrm{~cm}$ deep. Daily irrigation was performed. The percentage of emerged seedlings was determined 14 DAS.

\section{Seedling growth in uncontrolled environment}

At the end of the seedling emergence test (14 days), 20 seedlings of each replication were chosen randomly, taken from the sand, washed with water, dried with paper towels, and measured with a graduated ruler. Then, the seedlings were placed in paper bags and placed in the stove for drying and the subsequent determination of dry matter according to the methodology described by Nakagawa (1999).

\section{Endosperm use efficiency test}

This was conducted under standard germination conditions and at low temperatures.

A) Standard germination conditions: four replications of 50 seeds from each treatment and each cultivar, separately, were distributed on paper 
towel rolls, composed of three leaves moistened with distilled water, with a weight equivalent to 2.5 times the weight of dry paper (BRAZIL, 2009). Then, the rolls containing the seeds were transferred to the germination chamber at $25^{\circ} \mathrm{C}$. After 72 hours, 10 seeds of each replicate were removed, the seedlings were separated from each seed and the seeds and seedlings were weighed, then they were dried. This procedure was repeated from the third to seventh day after sowing, yielding the dry weight of the seeds and seedlings and using these values to calculate the efficiency of endosperm use according to the formula proposed by Blum and Sinmena (1994).

B) Germination at low temperature: A similar procedure as described above was performed; however, the seeds were subjected to $10^{\circ} \mathrm{C}$ for 48 hours and then transferred to BOD at $25^{\circ} \mathrm{C}$.

A randomized block experimental design was used for seedling emergence test and a completely randomized design was used for the other tests. The results were submitted to analysis of variance and comparison of means by the Scott Knott test $(\mathrm{p}<0.05)$, separately for each cultivar.

\section{RESULTS AND DISCUSSION}

The results of the hydration curves (Figure 1) showed that priming with Stimulate $\AA$, boric acid and zinc sulfate increased the duration of phases I and II of germination, compared to hydropriming for both cultivars. Working with rice seeds, Yang et al. (2007) found that phases I and II may be extended with up to around 50 hours of soaking, depending on the cultivar, the seed moisture content, the degree of deterioration, and other factors. At these phases, various processes occur, such as the starch degradation, glycolysis and fermentation, starch synthesis, organization of mitochondria, amino acid biosynthesis, cell wall biosynthesis, protein degradation and lipid reserve accumulation. These are fundamental processes for the preparation for phase III, in which cell division and expansion occur along with the protrusion of the primary root and seedling growth.

A

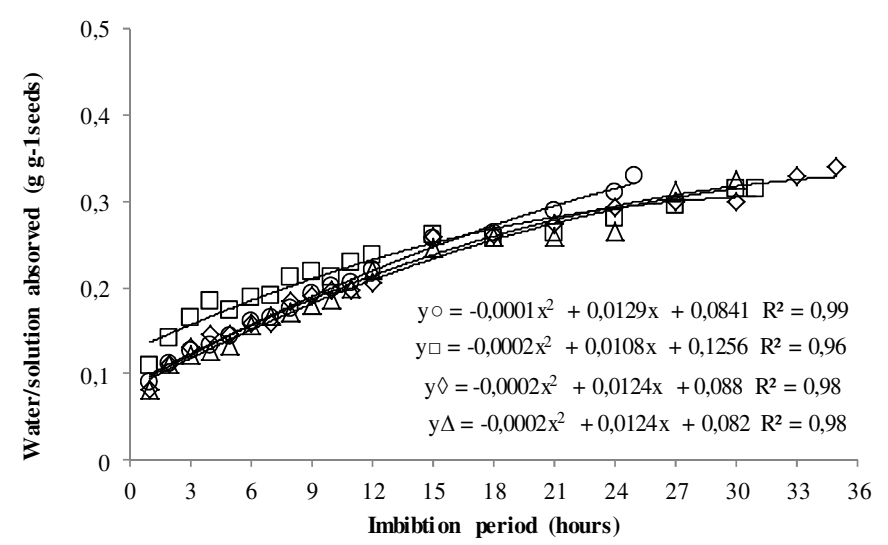

B

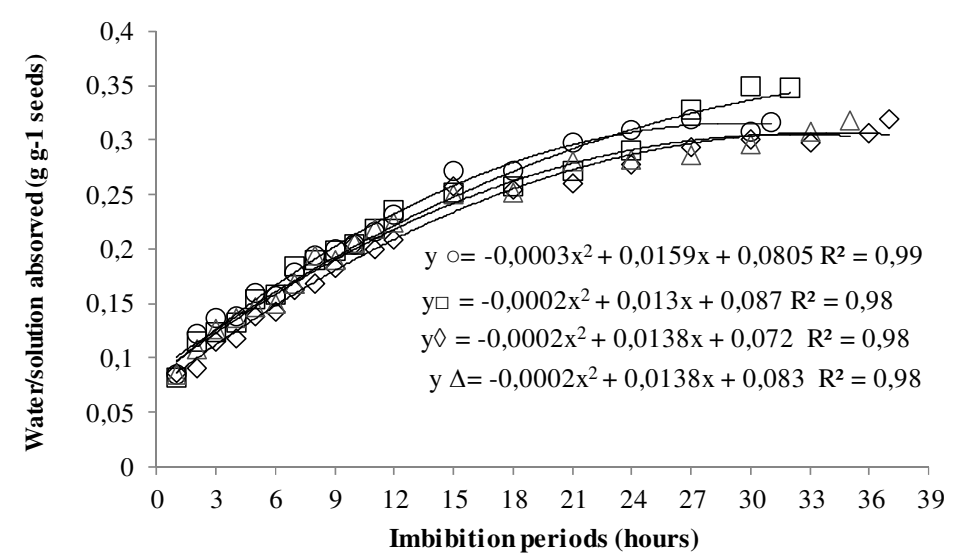

Figure 1. Seed imbibition curves of hydropriming $(\circ)$, Stimulate $(\square)$, boric acid $(\diamond)$ and zinc sulphate $(\Delta)$ rice primed seeds, cultivar Puitá (A) and Inov (B). 
It was observed that hydropriming as well as priming with Stimulate ${ }^{\circledR}$ and zinc sulfate increased rice seed germination for the Puita cultivar (Table 1). According to Varier et al. (2010), various subcellular changes occur as a function of seed priming; among these, the increase in protein synthesis related to the mobilization of reserves, DNA repair and cell cycle progression from G1 to G2 and increased production of ATP contribute to improving germination and physiological potential.

Table 1. Means of germination (G), endosperm use efficiency (EUE), seedling length (SL) and seedling dry mass (SDM) of rice seeds, cultivars Puitá Inta $\mathrm{Cl}$ and Inov $\mathrm{Cl}$, submitted to different seed priming procedures.

\section{Treatment}

$\begin{array}{ccccc}\text { Control Hydropriming } & \text { Stimulate Boric acid } & \begin{array}{c}\text { Zinc } \\ \text { sulphate }\end{array} & \text { CV (\%) } \\ \text { Cultivar } & \end{array}$

\section{Puitá}

\begin{tabular}{|c|c|c|c|c|c|c|}
\hline $\mathrm{G}(\%)$ & $91 b^{*}$ & $98 \mathrm{a}$ & 99 a & $92 \mathrm{~b}$ & $96 a$ & 3,2 \\
\hline EUE (\%) & $13 \mathrm{~b}$ & $19 \mathrm{~b}$ & $67 \mathrm{a}$ & $12 \mathrm{~b}$ & $75 \mathrm{a}$ & 17 \\
\hline $\mathrm{SL}(\mathrm{cm})$ & $14,2 \mathrm{~b}$ & $17,3 \mathrm{a}$ & $17,3 \mathrm{a}$ & $9,9 \mathrm{c}$ & $17,3 \mathrm{a}$ & 7,4 \\
\hline $\begin{array}{c}\text { SDM } \\
\left(\mathrm{mg} \mathrm{seedling}^{-1}\right)\end{array}$ & $8,1 \mathrm{a}$ & $8,7 \mathrm{a}$ & $8,6 \mathrm{a}$ & $5,9 \mathrm{~b}$ & $8,3 \mathrm{a}$ & 6,3 \\
\hline & \multicolumn{6}{|c|}{ Inov } \\
\hline $\mathrm{G}(\%)$ & $94 \mathrm{a}$ & $97 \mathrm{a}$ & $98 \mathrm{a}$ & $84 \mathrm{~b}$ & $98 \mathrm{a}$ & 1,0 \\
\hline EUE (\%) & $10 \mathrm{c}$ & $19 \mathrm{~b}$ & $20 \mathrm{~b}$ & $9 \mathrm{c}$ & $24 \mathrm{a}$ & 9,5 \\
\hline $\mathrm{SL}(\mathrm{cm})$ & $17,2 \mathrm{~b}$ & $17,8 \mathrm{a}$ & $18,8 \mathrm{a}$ & $3,1 \mathrm{c}$ & $16,5 \mathrm{~b}$ & 6,5 \\
\hline $\begin{array}{c}\text { SDM } \\
\left(\text { mg seedling }^{-1}\right)\end{array}$ & $9,4 \mathrm{a}$ & $9,9 \mathrm{a}$ & $9,4 \mathrm{a}$ & $5,5 \mathrm{c}$ & $8,2 \mathrm{~b}$ & 8,1 \\
\hline
\end{tabular}

However, for cultivar Inov, there was no improvement in the performance of seeds, and negative effects of conditioning with boric acid were observed. It is possible that a phytotoxic effect of boric acid occurred in this situation. It is known that boron is involved in various cellular processes such as cell division, and may therefore interfere in germination, considering that this involves division and cell elongation (BEWLEY et al., 2013). Working with rice seeds, Johnson et al. (2005) found that seeds subjected to priming with a solution of boric acid $(0.008 \mathrm{M})$ contained $12 \mathrm{mg}$ $\mathrm{kg}^{-1}$ of B after 36 hours of soaking, whereas unprimed seeds and seeds primed with $\mathrm{Zn}$ sulfate solution $(0.004 \mathrm{M})$ contained $1.5 \mathrm{mg} \mathrm{kg}^{-1}$, the same concentration used in this study. Therefore, B levels were higher in the seeds after priming, which could have interfered in the performance of the seeds in this study. Although these authors found positive results of priming, it is noteworthy that they used other cultivars. Still, related to the results of germination, with the use of the endosperm efficiency test (Table 1), it was observed that seed priming with boric acid for cultivar Inov caused a reduction in reserve mobilization, which may explain the reduction in germination with this treatment.

As for seedling growth, it was observed that hydropriming, as well as priming with Stimulate ${ }^{\circledR}$ and zinc sulfate allowed better performance for the Puita cultivar, as did hydropriming and priming with Stimulate ${ }^{\circledR}$ for cultivar Inov (Table 1). Hydropriming can promote seedling growth, since this synchronizes all cells in the embryo growth of G2 phase of the cell cycle; after imbibition, cell division proceeds uniformly in all cells, ensuring the 
development of all parts of the seedling (VARIER et al., 2010). Similar results were observed for rice seeds (MATSUSHIMA; SAKAGAMI, 2013) and wheat (BASRA et al., 2013).

As for the effect of priming with Stimulate ${ }^{\circledR}$ for seedling growth, it is likely that a beneficial effect occurred due to the composition of this growth promoter (cytokinin, gibberellin and auxin), as these growth regulators act in division, expansion and cell elongation and may thus contribute to this result. Similar results were obtained with sunflower seeds (SANTOS et al., 2013).

Priming with zinc sulfate increased seedling growth, probably since it provided a source of $\mathrm{Zn}$ which is required for tryptophan synthesis. This amino acid is the precursor for indole acetic acid (IAA), a growth regulator in the auxins group, which essential for all growth processes and plant development (ZHAO 2011). The metabolic pathway of tryptophan-dependent auxin synthesis is essential to embryogenesis, plant development and other physiological processes (CHENG et al., 2007; STEPANOVA et al., 2008; TAO et al., 2008), as well as for the control of root development (OVERVOORD et al., 2010).

However, in terms of seedling dry matter, no treatment was beneficial, and priming with boric acid reduced seed performance for both cultivars (Table 1). These results may be associated with low reserve mobilization in seeds primed with boric acid, which can be detected by means of the test of endosperm efficiency use (Table 1). According to Mallik et al. (1989), increases in rice seedling growth may be associated with increased endosperm size and embryo reserve content. Also, Teng et al. (1992) found in 38 rice cultivars that seeds with a higher weight originate seedlings with greater amounts of dry matter. So, if reserve mobilization is impaired, there is a high probability of reduced dry matter accumulation in the subsequent seedlings.

As for the germination test at low temperature, there was no effect of the treatments for both cultivars (Table 2). However, it is noteworthy that the control treatment had a high germination percentage, indicating the relative tolerance to low temperature stress. In relation to seedling growth at a low temperature, there were differences between the treatments; however, none of these caused improvements in seed physiological potential (Table 2), although the efficiency of endosperm use results revealed beneficial effects of hydropriming for cultivar Puita and priming with zinc sulfate for cultivar Inov (Table 1).

Table 2. Means of germination at low temperatures (GLT), endosperm use efficiency (EUE), seedling length (SL) and seedling dry mass (SDM) of rice seeds, cultivars Puitá Inta $\mathrm{Cl}$ and $\mathrm{Inov} \mathrm{Cl}$, submitted to different seed priming procedures.

\begin{tabular}{|c|c|c|c|c|c|c|}
\hline & \multicolumn{6}{|c|}{ Treatment } \\
\hline & Control & Hydropriming & Stimulate & Boric acid & $\begin{array}{c}\text { Zinc } \\
\text { sulphate }\end{array}$ & $\mathrm{CV}(\%)$ \\
\hline & \multicolumn{6}{|c|}{ Cultivar } \\
\hline & \multicolumn{6}{|c|}{ Puitá } \\
\hline GLT (\%) & $97 a^{*}$ & $98 \mathrm{a}$ & $97 \mathrm{a}$ & $96 \mathrm{a}$ & $98 \mathrm{a}$ & 6,2 \\
\hline EUE $(\%)$ & $3 \mathrm{c}$ & $5 \mathrm{a}$ & $4 \mathrm{~b}$ & $3 \mathrm{c}$ & $4 \mathrm{~b}$ & 12 \\
\hline $\mathrm{SL}(\mathrm{cm})$ & $12 \mathrm{a}$ & $7,8 \mathrm{c}$ & $10,4 \mathrm{~b}$ & $3,0 \mathrm{~d}$ & $6,5 \mathrm{c}$ & 13 \\
\hline \multirow[t]{2}{*}{$\begin{array}{c}\text { SDM } \\
\left(\mathrm{mg} \mathrm{seedling}^{-1}\right) \\
\end{array}$} & $8,1 \mathrm{a}$ & $8,7 \mathrm{a}$ & $8,6 \mathrm{a}$ & $5,9 \mathrm{~b}$ & $8,3 \mathrm{a}$ & 6,3 \\
\hline & \multicolumn{6}{|c|}{ Inov } \\
\hline GLT (\%) & $97 \mathrm{a}$ & 99 a & 99 a & 99 a & $97 \mathrm{a}$ & 6,8 \\
\hline EUE (\%) & $3 \mathrm{~b}$ & $4 \mathrm{~b}$ & $5 \mathrm{~b}$ & $4 \mathrm{~b}$ & $28 \mathrm{a}$ & 17 \\
\hline $\mathrm{SL}(\mathrm{cm})$ & $13,3 \mathrm{a}$ & $11,4 \mathrm{~b}$ & $11,5 \mathrm{~b}$ & $1,0 \mathrm{~d}$ & $7,9 \mathrm{c}$ & 13 \\
\hline $\begin{array}{c}\text { SDM } \\
\left(\mathrm{mg} \mathrm{seedling}^{-1}\right)\end{array}$ & $5,1 \mathrm{a}$ & $5,9 \mathrm{a}$ & $5,5 \mathrm{a}$ & $5,4 \mathrm{a}$ & $5,6 \mathrm{a}$ & 12 \\
\hline
\end{tabular}


It is important to mention that seed priming with boric acid significantly reduced seedling growth compared to the other treatments (Table 2). Similarly, seedling dry matter accumulation was not favored by any of the treatments, and priming with boric acid was detrimental to cultivar Puita (Table 2).
As for most of the variables analyzed, there was no beneficial effect of the treatments on seedling emergence, the percentage of emerged seedlings or seedling growth (Table 3). The percentage of seedling emergence was reduced by boric acid priming for cultivar Puita, as well as by zinc sulfate for cultivar Inov (Table 3).

Table 3. Means of seed emergency (SE), seedling length (SL) and seedling dry mass (SDM) of rice seeds, cultivars Puitá Inta $\mathrm{Cl}$ e Inov $\mathrm{Cl}$, submitted to different seed priming procedures.

\begin{tabular}{|c|c|c|c|c|c|c|}
\hline & \multicolumn{6}{|c|}{ Treatment } \\
\hline & Control & Hydropriming & Stimulate & $\begin{array}{c}\text { Boric } \\
\text { acid }\end{array}$ & $\begin{array}{c}\text { Zinc } \\
\text { sulphate }\end{array}$ & $\begin{array}{l}\mathrm{CV} \\
(\%)\end{array}$ \\
\hline & \multicolumn{6}{|c|}{ Cultivar } \\
\hline & \multicolumn{6}{|c|}{ Puitá } \\
\hline SE (\%) & $78 a^{*}$ & $79 \mathrm{a}$ & $71 \mathrm{a}$ & $15 \mathrm{~b}$ & $73 \mathrm{a}$ & 3,0 \\
\hline $\mathrm{SL}(\mathrm{cm})$ & $19,1 \mathrm{a}$ & $8,9 \mathrm{c}$ & $8,7 \mathrm{c}$ & $4,6 \mathrm{~d}$ & $10,3 \mathrm{c}$ & 5,5 \\
\hline \multirow[t]{2}{*}{$\begin{array}{c}\text { SDM } \\
\left(\mathrm{mg} \mathrm{seedling}^{-1}\right) \\
\end{array}$} & $10,5 \mathrm{a}$ & $6,3 \mathrm{c}$ & $5,6 \mathrm{~d}$ & $6,6 \mathrm{~b}$ & $7,1 \mathrm{~b}$ & 5,5 \\
\hline & \multicolumn{6}{|c|}{ Inov } \\
\hline SE (\%) & $88 \mathrm{a}$ & $81 \mathrm{a}$ & $84 \mathrm{a}$ & $6 \mathrm{c}$ & $63 \mathrm{~b}$ & 5,9 \\
\hline $\mathrm{SL}(\mathrm{cm})$ & $17,7 \mathrm{a}$ & $11,8 \mathrm{~b}$ & $11,1 \mathrm{~b}$ & $1,2 \mathrm{c}$ & $13,0 \mathrm{~b}$ & 9,9 \\
\hline $\begin{array}{c}\text { SDM } \\
\left(\mathrm{mg} \mathrm{seedling}^{-1}\right)\end{array}$ & $9,1 \mathrm{a}$ & $9,4 \mathrm{a}$ & $7,0 \mathrm{~b}$ & $6,3 \mathrm{~b}$ & $6,4 \mathrm{~b}$ & 6,9 \\
\hline
\end{tabular}

*Means followed by different letters in the line differ significantly by Scott Knott test $(\mathrm{p}<0,05)$.

Seedling length was reduced in all treatments, for both cultivars; however, we observed the most dramatic effects with boric acid (Table 3). It is important to mention that none of the treatments were effective in increasing seedling dry matter, and for cultivar Inov, Stimulate ${ }^{\circledR}$, boric acid and zinc sulfate priming resulted in lower seed performance (Table 3).

Although Johnson et al. (2005) reported on the benefits of rice seed priming with boric acid solution $(0.008 \mathrm{M})$, in the present study, this treatment caused negative effects for most characteristics. According to Fageria (1997), the appropriate level of B in rice shoots is around $20 \mathrm{mg}$ $\mathrm{kg}^{-1}$. As a consequence, levels above this value can be considered toxic. Considering the concentration used in this study, it is expected that the solution used had $16 \mathrm{mg} \mathrm{B} \mathrm{g}^{-1}$ seed, which is higher than levels listed as toxic by Fageria (1997). Although it cannot be confirmed that $\mathrm{B}$ was completely absorbed by the seeds, this level probably exerted toxic effects, thereby reducing their performance. According to Reid et al. (2004), B excess may cause the interruption of cell division and development.

Working with barley, Karabal et al. (2003) observed that exposure of wheat seedlings to B solutions at concentrations of 5 to $10 \mathrm{mM}$ caused damage to membranes, thereby increasing membrane permeability and the malondialdehyde content of the cell, which is an important marker of oxidative stress.

\section{CONCLUSION}

The priming procedures used in this study did not contribute to improving physiological potential of rice seeds for cultivars Puita Inta CL and Inov $\mathrm{Cl}$. Boric acid priming reduced seed performance. 
RESUMO: o condicionamento fisiológico é uma técnica que envolve a hidratação controlada das sementes que permite o início de processos de preparação para a germinação sem permitir que ocorra a protrusão da raiz. O objetivo deste estudo foi avaliar o efeito de diferentes procedimentos de condicionamento fisiológico no potencial fisiológico de sementes de arroz. Foram utilizadas sementes de arroz das cultivares Puita Inta CL e Inov CL, representadas por um lote cada. Os tratamentos consistiram de: controle, hidrocondicionamento, condicionamento com Stimulate ${ }^{\circ}$, com solução de ácido bórico e solução de sulfato de zinco, com quatro repetições. Previamente ao condicionamento, foram realizadas as curvas de hidratação. Após o condicionamento, as sementes foram avaliadas quanto à germinação, crescimento de plântulas, eficiência do uso do endosperma, germinação a baixas temperaturas e emergência das plântulas. Os procedimentos de condicionamento utilizados neste estudo não melhoraram o potencial fisiológico das sementes de arroz das cultivares de Puita Inta CL e Inov Cl. O condicionamento fisiológico de sementes de arroz com ácido bórico tem efeito negativo sobre o desempenho das sementes.

PALAVRAS CHAVE: Oryza sativa. Zinco. Ácido bórico. Stimulate ${ }^{\circledR}$

\section{REFERENCES}

AJOURI, A.; ASGEDOM, H.; BECKER, M. Seed priming enhances germination and seedling growth of barley under conditions of $\mathrm{P}$ and $\mathrm{Zn}$ deficiency. Journal of Plant Nutrition and Soil Science, Weinheim, v. 167, n. 5, p. 630-636, 2004. http://dx.doi.org/10.1002/jpln.200420425

BASRA, S. M. A.; PANNU, I. A.; AFZAL, I. Evaluation of seedling vigor of hydro and matriprimed wheat seeds. International Journal of Agriculture \& Biology, Faisalabad, v. 5 n. 2, p. 121-123, 2013.

BEWLEY, J. D.; BRADFORD, K., HILHORST, H., NONOGAKI, H. Seeds: physiology of development, germination and dormancy. New York: Springer. 2013.

BLUM, A.; SINMENA, B. Wheat seed endosperm utilization under heat stress and its relation to thermotolerance in the autotrophic plant. Field Crops Research, Amsterdam, v. 37, n. 3, p. 185-191, 1994. http://dx.doi.org/10.1016/0378-4290(94)90097-3

BRASIL. Ministério da Agricultura, Pecuária e Abastecimento. Regras para Análise de Sementes/Ministério da Agricultura, Pecuária e Abastecimento. Secretaria de Defesa Agropecuária. - Brasília, DF: MAPA/ACS, 2009. 399p.

CAKMAK, I. Role of zinc in protecting plant cells from reactive oxygen species. New Phytologist, Cambridge, v. 146, n. 2, p. 185-205, 2000. http://dx.doi:10.1046/j.1469-8137.2000.00630.x

CHENG, Y.; DAI, X.; ZHAO, Y. Auxin synthesized by the YUCCA flavin monooxygenases is essential for embryogenesis and leaf formation in Arabidopsis. Plant Cell, Rockville, v. 19, n. 8, p. 2430-2439, 2007. http:/dx.doi.org/10.1105/tpc.107.053009.

FAGERIA, N. K.; BALIGAR, V. C.; JONES, C. A. Growth and mineral nutrition of field crops. New York: Marcel Dekker, 1997.

FAROOQ, M.; WAHID, A.; SIDDIQUE, K.H.M. Micronutrient application through seed treatments- a review. Journal of Soil Science and Plant Nutrition, v. 12, n. 1, p. 125-142, 2012. http://dx.doi.org/10.4067/S071895162012000100011.

GHOBADI, M.; ABNAVI, M. S.; HONARMAND, S. J; GHOBADI, M. E.; MOHAMMADI, G. R. Effect of hormonal priming $\left(\mathrm{GA}_{3}\right)$ and osmopriming on behavior of seed germination in wheat. Journal of Agricultural Science, Cambridge, v. 4, n.9, p. 244-250, 2012. http://dx.doi.org/10.5539/jas.v4n9p244 
IMRAN, M.; MAHMOOD, A.; ROMHELD, V.; NEUMANN, G. Nutrient seed priming improves seedling development of maize exposed to low root zone temperatures during early growth. European Journal of Agronomy, v. 49, p. 141-148, 2013. http://dx.doi:10.1016/j.eja.2013.04.001

JOHNSON, S. E.; LAUREN, J.G.; WELCH, R. M.; DUXBURI, J. M. A comparison of the effects of micronutrient seed priming and soil fertilization on the mineral nutrition of chickpea, lentil, rice and wheat in Nepal. Experimental Agriculture, Cambridge, v. 41, n. 4, p 427-448, 2005.

http://dx.doi.org/10.1017/S0014479705002851.

KARABAL, E.; YUCEL, M.; OKTEM, H. A. Antioxidant responses of tolerant and sensitive barley cultivars to boron toxicity. Plant Science, Limerick, v. 164, n. 6, p. 925-933, 2003. http://dx.doi.org/10.1016/S01689452(03)00067-0.

MALLIK, S.; AGUILAR, A. M.; VERGARA, B. S. Heterosis and heterobeltiosis for high density grain index and other rice characters. International Rice Research Newsletter, v. 14, n. 1, p. 10-11, 1989.

MATSUSHIMA, K. I; SAKAGAMI, J. I. Effects of seed hydropriming on germination and seedling vigor during emergence of rice under different soil moisture conditions. American Journal of Plant Sciences, v. 4, n. 8, p. 1584-1593, 2013. http://dx.doi.org/10.4236/ajps.2013.48191.

MUHAMMAD, I.; KOLLA, M.; VOLKER, R.;GUNTER, N. Impact of Nutrient Seed Priming on Germination, Seedling Development, Nutritional Status and Grain Yield of Maize. Journal of Plant Nutrition, v. 38, n. 12, p. 1803-1821, 2015. http://dx.doi.org/10.1080/01904167.2014.990094

NAKAGAWA, J. Testes de vigor baseados na avaliação de plântulas. In: KRZYZANOWSKI, F. C.; VIEIRA, R.D.; FRANÇA-NETO, J. B. (Ed.). Vigor de sementes: conceitos e testes. Londrina: ABRATES, 1999.

OVERVOORD, P.; FUKAKI, H.; BEECKMAN, T. Auxin Control of Root Development. Cold Spring Harb Perspectives in Biology, Cold Spring Harbor, v. 2, n. 1, p. 01-16, 2010.

http://dx.doi.org/10.1101/cshperspect.a001537.

OZTURK, L.; YAZICI, M. A.; YUCEL, C.; TORUN, A.; CEKIC, C.; BAGCI, A.; OZKAN, H.; BRAUN, H.; SAYERS, Z.; CAKMAK, I. Concentration and localization of zinc during seed development and germination in wheat. Physiologia Plantarum, Copenhagen, v. 128, n. 1, p. 144-152, 2006.

http://dx.doi.org/10.1111/j.1399-3054.2006.00737.x.

REID, R. J.; HAYES, J. E.; POST, A.; STANGOULIS, C. R.; GRAHAM, R. D. A critical analysis of the causes of boron toxicity in plants. Plant Cell Environment, Oxford, v. 27, n. 11, p. 1405-1414, 2004. http://dx.doi.org/10.1111/j.1365-3040.2004.01243.x.

SANTOS, C. A. C.; PEIXOTO, C. P.; VIEIRA, E. L.; CARVALHO, E. V.; PEIXOTO, V. A. B. Stimulate $^{\circledR}$ na germinação de sementes, emergência e vigor de plântulas de girassol. Bioscience Journal, Uberlândia, v. 29, n. 3, p. 605-616, 2013.

STEPANOVA, A. N.; ROBERTSON-HOYT, J.; YUN, J.; BENAVENTE, L. M.; XIE, D. Y.; TAA1-mediated auxin biosynthesis is essential for hormone crosstalk and plant development. Cell Press, Philadelphia, v. 133, n. 1, p. 177-191, 2008. http://dx.doi.org/10.1016/j.cell.2008.01.047.

TAO,Y.; FERRER, J. L.; LJUNG, K.; POJER, F.; HONG, F.; LONG, J.A.; LI, L.; MORENO, J. E.; BOWMAN, M. E.; IVANS, L. J.; CHENG, Y.; LIM, J.; ZHAO, Y.; BALLARÉ, C. L.; SANDBERG, G.; NOEL, J. P.; CHORY, J. Rapid synthesis of auxin via a new tryptophandependent pathway is required for shade avoidance in plants. Cell Press, Philadelphia, v. 133, n. 1, p. 164-176, 2008.

http://dx.doi.org/10.1016/j.cell.2008.01.049. 
TAYLOR, A. G.; ALLEN, P. S.; BENNETT, M. A.; BRADFORD, K. J.; BURRIS, J. S.; MISRA, M. K. Seed enhancements. Seed Science Research, Wallingford, v. 8, p. 245-256, 1998. :

http://dx.doi.org/10.1017/S0960258500004141

TENG, S.; VERGARA, B. S.; ALEJAR, A. A. Relationship of grain length, width and weight to seedling vigor in rice. Philippine Journal of Crop Science, v. 17, p. 17-20, 1992.

VARIER, A.; VARI, A. K.; DADLANI, M. The subcellular basis of seed priming. Current Science, Bengaluru, v. 99, n. 4, p. 450-456, 2010.

ZAMAN, B.; ALI, A.; HYDER, S.I.; ARSHADULLAH, M.; BHATTI, S.U. Potasssium chloride as a nutrient seed primer to enhance salt-tolerance in maize. Pesquisa Agropecuária Brasileira, Brasília, v.47, n.8, p.11811184, 2012.

ZHAO, Y. Auxin biosynthesis: a simple two-step pathway converts tryptophan to indole-3-acetic acid in plants. Molecular Plant, Maryland Height, v. 5, n. 2, p. 334-338, 2011. http://dx.doi.org/10.1093/mp/ssr104

YARNIA, M.; TABRIZI, E. F. M. Effect of seed priming with different concentration of GA3, IAA and Kinetin on azarshahr onion germination and seedling growth. Journal of Basic and Applied Science Research, Cairo, v. 2, n. 3, p. 2657-2661, 2012. 